S. Afr. J. Agric. Ext.,

Zwane

Vol. 44, No. 2, 2016: $71-83$

DOI: http://dx.doi.org/10.17159/2413-3221/2016/v44n2a391

(Copyright)

\title{
PERCEPTIONS OF EXTENSION ADVISORS ON PRIVATIZATION AND OUTSOURCING AS AN OPTION FOR DEVELOPMENT PARADIGM IN LIMPOPO PROVINCE AND THE LESSONS FOR FUTURE
}

Zwane ${ }^{15}$, E. M.

\section{ABSTRACT}

There is no one set of challenges that justify privatization of extension and advisory services both in developed and developing areas. It is argued that factors that can influence privatization include; limited budget provisions and ineffectiveness of extension and advisory services. Literature is full of lessons on the failure and success of privatization in organizations in different regions of the world both developed and underdeveloped as indicated in the studies commissioned by the World Bank, unfortunately South Africa was not part of the study. It is for this reason that this study was conducted in Limpopo Province of South Africa in order to establish the acceptability or non-acceptability of privatization and outsourcing.

The paper explores options for privatisation in South Africa with a focus in Limpopo Province. A sample of 324 extension officers out of 700 extension officers from the province was taken from the five districts of Limpopo constituting a sample of $46 \%$, and their opinions were gathered through quantitative design. The results show that extension efficiency was falling below the international standards when measured through the input/output ratio of 100/130. The majority of extension advisors (70\%) showed resistance to privatization, and the mean scale of the benefits of privatization was rated 6.7 as the highest in 7 categories. The extension advisors did not perceive any benefits for privatization hence rated $38 \%$ from all the districts. The paper concludes with recommendations that warn that privatization is ought to be taken with great care because the marginalized and the small scale farmers cannot afford to pay for extension services.

Keywords: privatization, outsourcing, advisory services, extension.

\section{INTRODUCTION}

Different forms of privatization become fashionable in many countries both developed and developing in the 1980's. Privatisation means different things to different people. According to Düvel (2002:161), privatisation implies full transfer of ownership from government to a private entity, with that entity meeting all costs and receiving all profits. In most cases governments have not privatised their extension services in this sense. Many authors agreed on the reasons for privatisation of agricultural extension which include budgetary cut backs and the general pressure to reduce state spending (Umali, 1996, Kraft; 1997).

Extension is faced with challenges such as lack of competence in certain specialized fields by extensionists, and this suggests that alternative ways of providing and funding the extension services need to be investigated. The objectives of the study are as follows:

- To investigate the relevancy of privatisation in Limpopo.

- To investigate the benefits of privatisation.

\footnotetext{
${ }^{15}$ Associate Professor in Agricultural Extension in the Centre of Rural and Community Empowerment CRE) school of Agriculture and Environmental Affairs, University of Limpopo. Email: zwanefrank@ gmail.com.
} 
S. Afr. J. Agric. Ext.,

Zwane

Vol. 44, No. 2, 2016: $71-83$

DOI: http://dx.doi.org/10.17159/2413-3221/2016/v44n2a391

- To investigate the possibility of outsourcing and co-financing.

(Copyright)

\section{THEORETICAL BACKGROUND}

Privatisation of extension received attention during the 1980s and 1990s and a number of studies were conducted either to justify or to express the perceptions of those who were closely affected such as the extension advisors and farmers. The main reason for privatisation pointed was that public extension was not effective or efficient as compared to Private or Non -Governmental Organizations (NGOs). Ehret (1997:227) maintained that Non-Government Organisations (NGOs) have enjoyed considerable success over the past decades, especially in the 1980s. NGOs see themselves mainly in contrast to governments and their institutional partners on the premise that they are not bureaucratic, not rigid, not directive and not stultifying of local initiatives. NGOs have played a role in agricultural extension in countries such as Bangladesh (Uddin \& Gao, Mamud-Ur-Rashid, 2014).

Three NGOs were identified as some of those that have played a role namely; Winrock International, World Vision, and Care International, (MEAS) 2014). Many scholars (Rivera \& Carry 1997:205, Umali, 1996, Kidd, Lamers, Ficarelli \& Hoffman, 1998:8 and Düvel, 2002: 168) report that privatization has positive impacts on extension delivery, and more specifically in regard to accountability (usually expressed in client orientation and satisfaction) improved efficiency, cost-effectiveness, and reduced public sector costs. A study was conducted in India to find out the attitudes of farmers towards privatization and the results was positive, out of 720 farmers interviewed, 48 percent were willing to pay for the services (Saravanian, 1999; Venkata, 2000). In another study conducted in Uganda it was found not so promising, for example out of 5363 respondents that were interviewed, 35 percent were willing to pay for information related to crops and animal production (Ozor, 2011), in contrast to a developed country such as Germany the findings was different, where 82.3 percent were willing to pay for private services (Ozor 2011).

Experiences related to privatization in the world vary from a complete withdrawal of state interventions, to a commercialization, and cost recovery approach (Kidd, et al (1998:3). In some instances it also means an increased involvement of the public services in income generating activities, which include the sale of seeds, surplus land and produce as well as the sale of publications and other materials. There are alternatives within privatization which could be pursued. According to Stillwell \& Botha (1997:7) a complete privatization of agricultural extension services is often not feasible. Düvel (2002) observes that an alternative solution to the problems of fiscal sustainability and poor client orientation is the integration of the private sector into extension systems. An example given in three countries where alternate funding was tried in research showed little positive evidence. The three countries are Kenya Research Institute (KARI) in Kenya (Beynon \& Mbogo, 1996), research in Zimbabwe (Beynon \& Mudimu, 1996) and voucher system in Chile (Bebbington \& Sotomayor, 1995). The Chilean example of voucher has to be adapted later. In a study conducted in 12 countries which included Mali, Honduras, UK, Venezuela, Ecuador, Estonia, Pakistan, Zimbabwe, Kenya Niger and Venezuela, about privatization (Rivera \& Alex, 2004), it was found that it can take different forms such as sub-contracting, outsourcing, or co-financing that it can form new partnerships and associations that provided capacities as opposed to ceding of total control (Connolly, 2004, Düvel, 2002). The study shows that affordability and efficiency of delivery are the main considerations that independently of each other can compel any 
S. Afr. J. Agric. Ext.,

Zwane

Vol. 44, No. 2, 2016: $71-83$

DOI: http://dx.doi.org/10.17159/2413-3221/2016/v44n2a391

(Copyright)

organization such as Department of Agriculture to privatize its extension service especially when the budget is not available (Düvel, 2002:160).

\section{METHODOLOGY}

The initial involvement was in the form of a national workshop to which every one of the nine provinces was invited to send a delegation of about 10 representatives. Other role players invited were NGOs, farmer organizations, research institutions and tertiary education institutions.

The workshop, in general, was conducted in such a way as to facilitate the gathering of ideas, viewpoints, opinions, suggestions, etc., but also to allow a selection of the more valuable and founded viewpoints. The methods used within the group sessions involved nominal group techniques to ensure that no potential contributions were overlooked or overruled. This was invariably followed by Delphi procedures to facilitate interaction and the possibility for participants to associate themselves with viewpoints they believed to be the well founded.

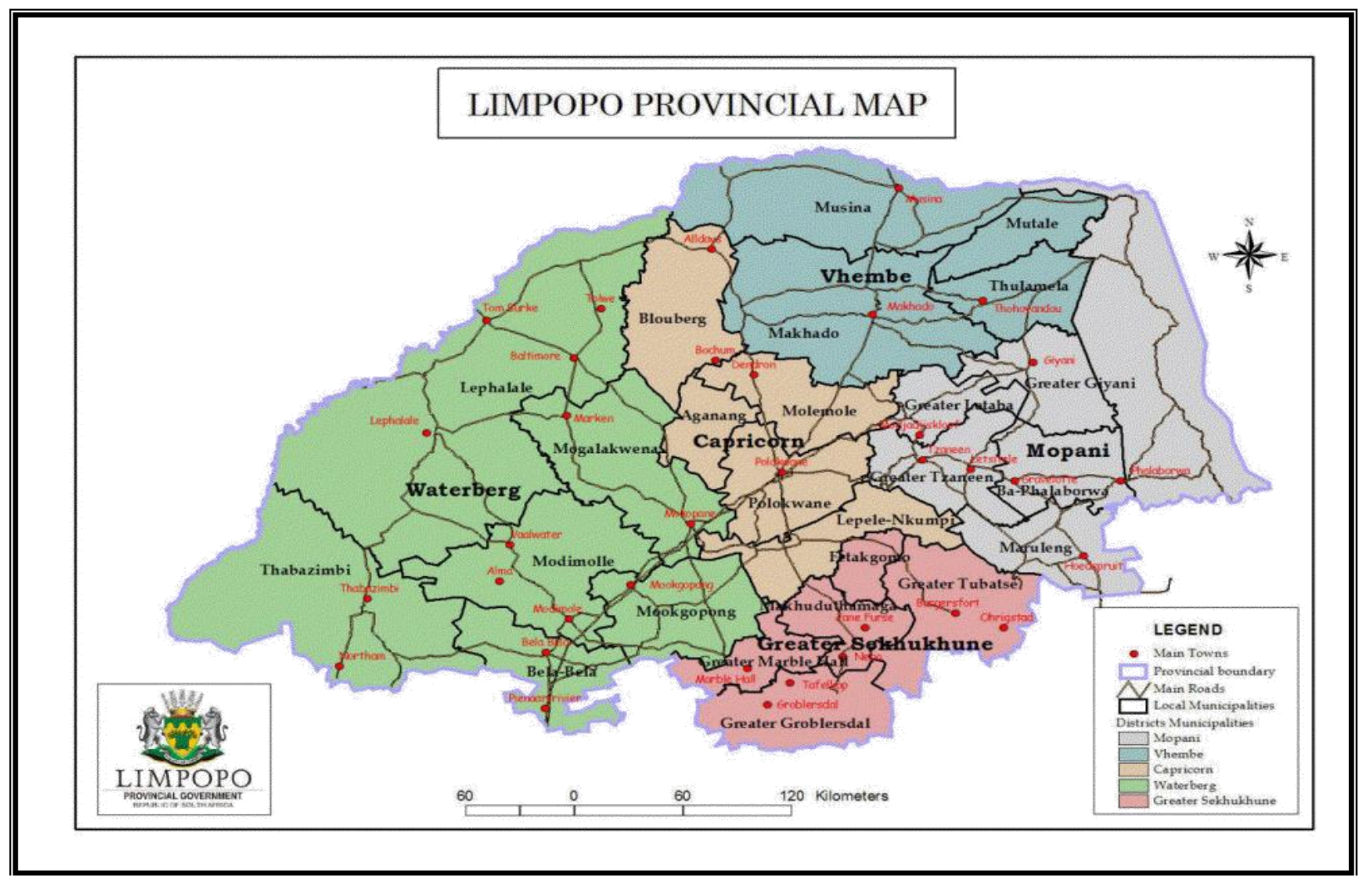

Figure 1: Map of Limpopo province depicting districts

Three hundred and twenty four (324) officers out of 700 extension officers from the province were involved in the group discussions constituting 40.50 percent. The findings on the perceptions of the respondents are discussed in the next section.

\section{FINDINGS AND DISCUSSION}

\subsection{The relevancy and importance of privatisation in Limpopo}


Vol. 44, No. 2, 2016: $71-83$

DOI: http://dx.doi.org/10.17159/2413-3221/2016/v44n2a391

(Copyright)

Respondents were requested to judge the efficiency of the Department of Agriculture's extension in Limpopo compared to an assumed average international efficiency of 130 percent, i.e. a R130 return per R100 invested in extension. The responses are presented in Figure 2.

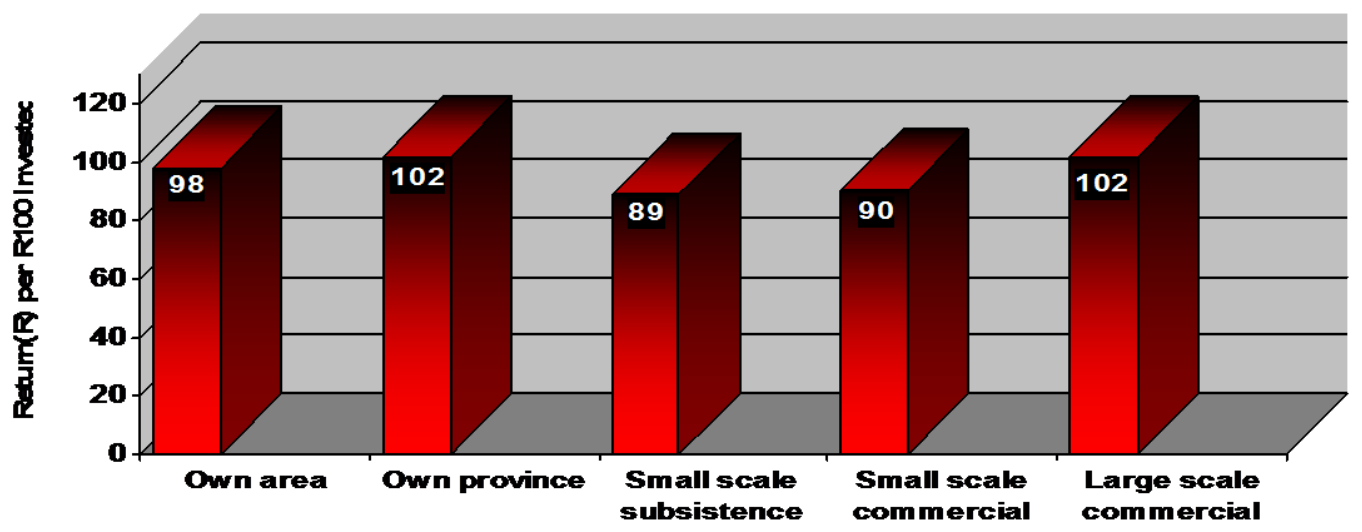

Figure 2: The mean efficiency assessments of the Department of Agriculture's extension service in different situations expressed as an output per R100 input

The perception of the respondents as reflected in Figure 2 suggest that the efficiency of extension, measured in terms of an input/output ratio, falls well below international standards, which is assumed to be an input/output ratio of 100/130. There is a perceived increase in extension efficiency from small-scale subsistence, to small scale commercial and to large-scale commercial farming, but the difference is marginal (i.e. between 10 and 20 percent).

These figures are mere judgements and are not based on empirical data, but the fact that the efficiency in the own area was rated lower than that of the rest of the province, does give an indication of a certain degree of rationalism, albeit a form of frustration with the current situation. Further evidence of the low efficiency of the public extension service is provided in Table 1, which reflects respondents' response to a question as to how much more efficient the extension service would have to become over the short and long term in order to escape the " threat" of privatisation.

Table 1: Respondents' assessment of the mean percentage efficiency increase that is essential over the short and long-term to avoid privatisation in the different districts

\begin{tabular}{|c|c|c|}
\hline \multirow{2}{*}{ Districts } & \multicolumn{2}{|c|}{ Required mean \% increase in efficiency } \\
\hline & Short term & Long term \\
\hline Sekhukhune & 120.10 & 113.36 \\
\hline Mopani & 140.26 & 139.10 \\
\hline Vhembe & 142.64 & 137.07 \\
\hline Bohlabela & 128.43 & 122.66 \\
\hline Capricorn & 123.49 & 136.74 \\
\hline Waterberg & 166.07 & 146.07 \\
\hline Total (Limpopo) & 131.04 & 131.42 \\
\hline Total (South Africa) & 134.21 & 139.00 \\
\hline
\end{tabular}


S. Afr. J. Agric. Ext.,

Zwane

Vol. 44, No. 2, 2016: $71-83$

DOI: http://dx.doi.org/10.17159/2413-3221/2016/v44n2a391

(Copyright)

The average opinion in Limpopo is that the efficiency will have to increase by about 31 percent over the short and long term, which is very similar to the mean applicable to the whole of South Africa. However the differences between the districts in Limpopo are very significant and vary by up to 40 percent. The biggest concern is in Waterberg District where it is believed that the efficiency of extension delivery needs to improve by about 46 percent. This concern can be interpreted as reflecting a certain need and thus representing a precondition for change.

To some degree qualification appears to play a role in the sense that respondents with a degree or advanced diploma (in extension) tend to be more critical of the current extension performance, while the district variation could be an indication of the critical influence of management. In view of a performance assessed by several categories of respondents to have to improve by 40 to 60 percent, the question of privatisation is justified. However, it is unlikely to be a general solution. Scholars like Botha \& Stilwell (1997:7) even warn that privatisation of extension services in South Africa may not be a good option.

\subsection{Extension efficiency}

Ehret (1997:226) maintains that NGOs like to see themselves being associated with issues like reaching out for the poor, participation, process versus outcome, contrast with the public sector, people-centred development, flexibility and experimentation, institution-building and cost effectiveness. Respondents were asked to assess the efficiency of the Department of Agriculture and the NGOs. A comparison of efficiency between government and nongovernment organizations is summarized in Figure 3. 


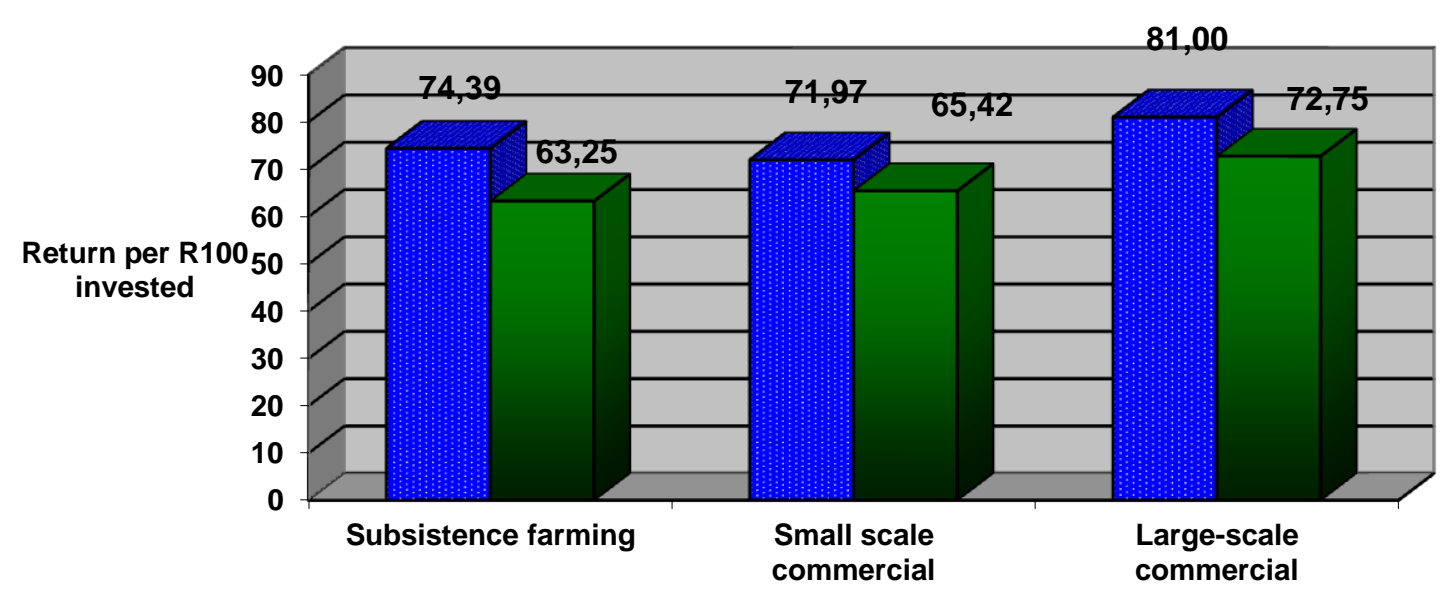

\section{口Govt. Organisations घNGOs}

Figure 3: A comparative efficiency assessment by respondents of the extension of Government and non-government organizations in different farming situations

The findings in Figure 3 show that the efficiency of NGOs is assessed to be lower in all categories of farming (than the state) with the biggest difference occurring in the small-scale subsistence situation. On average the efficiency of NGOs is assessed to be 11.7 percent lower than that of the public service (Department of Agriculture). This discrepancy is appreciable, but significantly less than the 17.3 made by a countrywide assessment (Düvel, 2002:161). The reason for this difference lies primarily in the variations among the districts in Limpopo.

In half of the districts the efficiency of NGOs is assessed to be higher than that of the Department of Agriculture and can be attributed to the positive impact of the activities of the German Technical Cooperation (GTZ) project and the Broadening of Agricultural Services and Extension and Delivery (BASED) programme focused on small communities. The main differences, however, stem from the drastic differences in levels of efficiency. In Sekhukhune District the return per R100 invested in extension was assessed to be R45 and R43 for the government service (Department of Agriculture) and NGOs respectively, while the assessments in Bohlabela were R123 and R122 respectively for the two types of services. Because of possible bias on the side of the respondents, this need not necessarily correspond with reality.

\subsection{Opinions on privatization}

Respondents were asked to indicate whether they agreed with the privatization of extension services in the Department of Agriculture. Figure 4 summarizes respondents' opinions regarding their agreement with privatization under various circumstances. 
Vol. 44, No. 2, 2016: $71-83$

DOI: http://dx.doi.org/10.17159/2413-3221/2016/v44n2a391

(Copyright)

\section{When the Government can no longer afford it (no funds) \\ When private organisations provide the service with own funds, albeit at a lower efficiency}

When private organisations can provide the service as effectively

When private organisations can provide the service more effectively

When the Department or its personnel no longer has the ability to provide the service

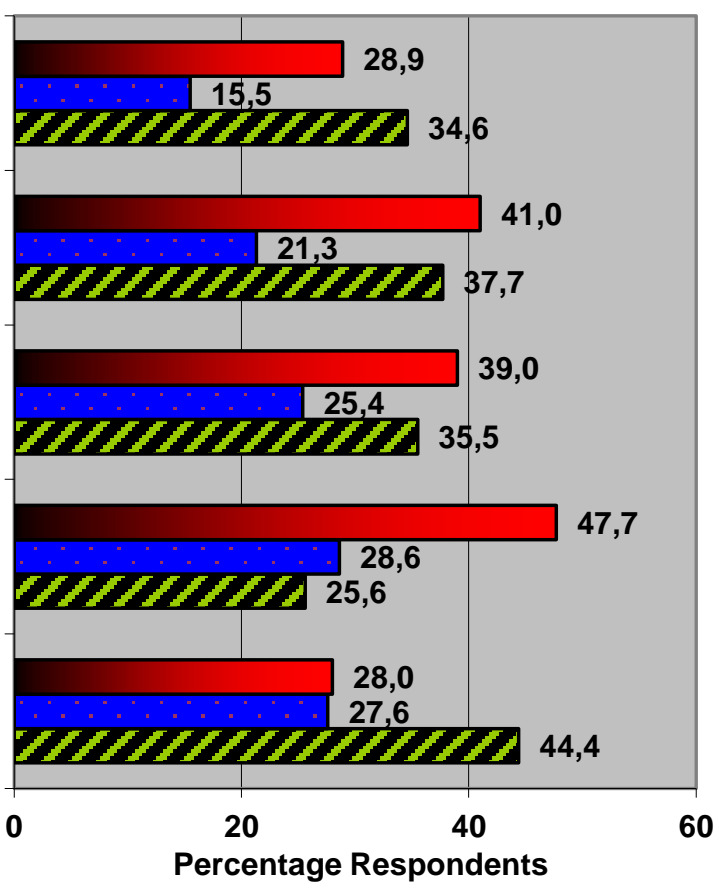

Percentage Respondents

\section{Disagree with privatisation $\square$ Hesitant/Don't know $\square$ Agree with privatisation}

Figure 4: Percentage distributions of respondents according to their agreement with privatization under different circumstances

The general opinion is that there is overwhelming resistance against privatisation. Only in circumstances where the Department of Agriculture or its personnel no longer have the ability to provide the service, do the majority ( 44.4 percent) agree to privatisation. Even where private organisations can provide the service more effectively, only 25.6 percent of the respondents were in favour of privatisation. Even non-affordability is not accepted by the majority (namely more than 70 percent) as a sufficient argument in favour of privatisation. This leads to the conclusion that privatisation is an emotional issue that does not even allow a rational debate and behind it possibly the fear of not meeting the challenge or unemployment. The findings in Figurer 4 relate to respondents' perception about the appropriateness of privatisation in certain hypothetical situations. Respondents were also asked to what degree the various circumstances do in fact apply in their situation. Table 2 summarizes the results. 
Table 2: The mean relevancy assessment by respondents of different circumstances in the different districts of Limpopo, based on a 10- point scale**

\begin{tabular}{|c|c|c|c|c|c|}
\hline District & $\begin{array}{c}\text { The DOA* or } \\
\text { its personnel } \\
\text { no longer have } \\
\text { the } \\
\text { competence or } \\
\text { ability to } \\
\text { provide the } \\
\text { service }\end{array}$ & $\begin{array}{c}\text { Private } \\
\text { organisations } \\
\text { can provide } \\
\text { the service } \\
\text { more } \\
\text { effectively } \\
\text { (better input- } \\
\text { output ratio) }\end{array}$ & $\begin{array}{c}\text { Private } \\
\text { organizations } \\
\text { can provide } \\
\text { service as } \\
\text { effectively }\end{array}$ & $\begin{array}{c}\text { Private } \\
\text { organisations } \\
\text { provide the } \\
\text { service with } \\
\text { own funds, } \\
\text { albeit at a } \\
\text { lower } \\
\text { efficiency }\end{array}$ & $\begin{array}{l}\text { Government } \\
\text { can no longer } \\
\text { afford it (no } \\
\text { funds) }\end{array}$ \\
\hline Sekhukhune & 4.90 & 5.44 & 5.34 & 4.74 & 5.38 \\
\hline Mopani & 5.31 & 6.39 & 5.71 & 5.51 & 5.17 \\
\hline Vhembe & 4.08 & 3.63 & 4.11 & 4.06 & 4.26 \\
\hline Bohlabela & 4.09 & 4.07 & 4.53 & 4.38 & 5.10 \\
\hline Capricorn & 4.83 & 4.87 & 4.99 & 5.11 & 4.85 \\
\hline Waterberg & 4.27 & 4.36 & 4.23 & 4.85 & 5.79 \\
\hline Total & 4.65 & 4.84 & 4.92 & 4.81 & 5.02 \\
\hline
\end{tabular}

** 10 -Point scale with $1=$ irrelevant and $10=$ highly relevant

* Department of Agriculture

The relatively low assessments in the large majority of cases less than half on a 10-point scale indicate that the circumstances that normally justify privatisation are not perceived to really apply to the respondents' districts. These findings are further evidence of the lacking of support for privatisation in the Limpopo Province. This is not an isolated case. According to Düvel (2002) similar perceptions apply to the rest of South Africa.

\section{BENEFITS OF PRIVATISATION}

Some countries in the world, have commercialized government owned extension systems, (for example Venezuela, The Netherlands and New Zealand) or by introducing user charges and cost recovery strategies (for example Chile, Venezuela and Colombia) (Kraft, 1997). The primary reason for the commercialisation of extension is the improvement of efficiency in delivery and unaffordability due to budgetary cut-backs. The Dutch extension service experienced a number of problems before commercialization. Tacken (1996:2) lists the following:

- High costs and low impact of extension programmes;

- Increasing staff numbers, whereas the number of farmers was declining;

- Growing conflicts between farmer's interests and policy goals such as raising production versus environmental problems and high cost of subsidies;

- $\quad$ Loss of some qualified staff (many of whom started working as consultants);

- Service was not needs driven i.e. advice was general not problem -oriented;

- Policy goals were given priority over farmer goals;

- No financial incentives to reward good performance; and

- Lack of job satisfaction.

According to Tacken (1996:2) the situation has changed with commercialization and benefits like increased efficiency, increased quality and client orientation, increased job satisfaction, more interaction between client and advisor, more effective and needs-driven extension. Respondents were requested to respond to a list of benefits claimed to be associated with privatisation and to assess their validity. Their views are summarized in Table 3. 
Table 3: Respondents' perception (expressed as a mean scale point assessment) of the validity of different aspects claimed to be benefits of privatisation

\begin{tabular}{||ll|c||}
\hline \multicolumn{1}{|c|}{ Benefits of Privatization } & $\begin{array}{c}\text { Mean } \\
\text { Scale } \\
\text { point }\end{array}$ \\
\hline 1) & Greater operational efficiency and cost effectiveness & 5.6 \\
\hline 2) & Greater accountability of extensionists to perform and produce results. & 6.7 \\
\hline 3$)$ & $\begin{array}{l}\text { Contractor (government) can demand a service standard from the agent } \\
\text { that government cannot deliver by itself. }\end{array}$ & 5.4 \\
\hline 4$)$ & $\begin{array}{l}\text { Contractor (government) can specify clients to be served (small, poor and } \\
\text { marginal farmers). }\end{array}$ & 5.3 \\
\hline 5) & $\begin{array}{l}\text { Reduces permanent staff requirements and allows redeployment of } \\
\text { resources to higher-priority or sensitive areas. }\end{array}$ & 4.5 \\
\hline 6) & $\begin{array}{l}\text { Enhances extension impact by accessing providers with special skills or } \\
\text { comparative advantages in providing specific services. }\end{array}$ & 6.0 \\
\hline 7) & Creates partnerships and working relationships with other providers. & 6.2 \\
\hline 8$)$ & $\begin{array}{l}\text { Enhances flexibility and credibility in responding to special needs of } \\
\text { diverse clientele. }\end{array}$ & 5.5 \\
\hline 9) & Is useful for testing innovative and higher risk "new" systems. & 5.4 \\
\hline 10) & Increases provider accountability. & 6.2 \\
\hline
\end{tabular}

The overall impression gained from the respondents' viewpoint summarised in Table 3, is that even the undeniable benefits are not strongly supported. Perhaps the strongest agreement is the greater accountability of extensionists and the pressure to perform and produce results (mean assessment of 6.7 scale points). The agreement, however, does not yet reflect enthusiasm and support. In fact, the mean acceptability assessments are very low supported by Figure 5 .
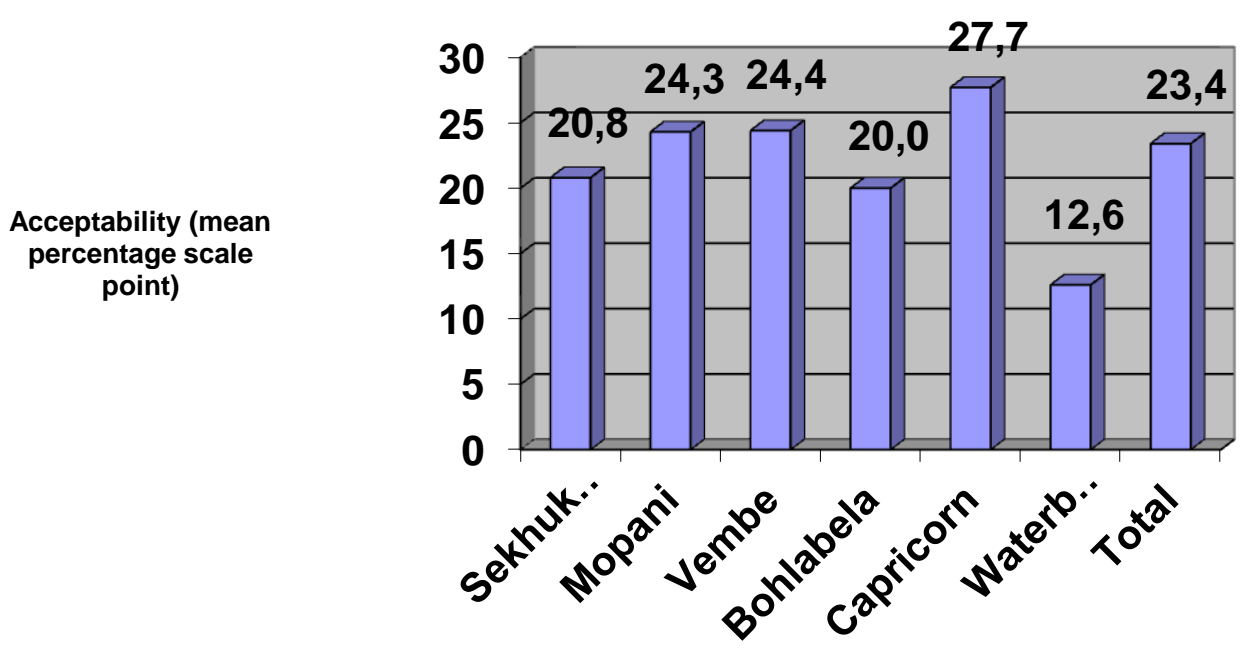

Figure 5: Assessments of the acceptability of privatization (expressed as a mean percentage scale point) by respondents in the different Districts

The overall impression of the findings in Figure 5 is that there is an extremely low assessment of the acceptability of privatisation in the Limpopo Province. Admittedly, there are differences between the districts, varying from a percentage scale point assessment of 
Vol. 44, No. 2, 2016: $71-83$

DOI: http://dx.doi.org/10.17159/2413-3221/2016/v44n2a391

(Copyright)

12.6 in Waterberg to 27.7 in Capricorn. The possible reason for this low assessment could be related to a fear or insecurity of employment by the extensionists. Düvel (2002:167) finds that the lack of support or the opposition to privatisation is not necessarily an issue of ignorance, because higher qualified respondents (measured in terms of total years of formal education) appeared to be more opposed to privatisation. The most outspoken category of extensionists is the younger and lower ranks as opposed to the managers.

\section{OUTSOURCING AND CO-FINANCING}

These are forms of institutional pluralism and can result in a complementation, but require of the central government to adjust to a position of reduced direct control over either programming or staffing. This can imply one or more of the following: unlinking public funding from public delivery, changes in governance and investing more broadly in the whole agricultural knowledge and information system (Düvel, 2002).

Respondents were asked to compare the acceptability of three alternatives namely in-sourcing of management / knowledge, outsourcing of personnel and outsourcing of total service. The findings are summarized in Figure 6.

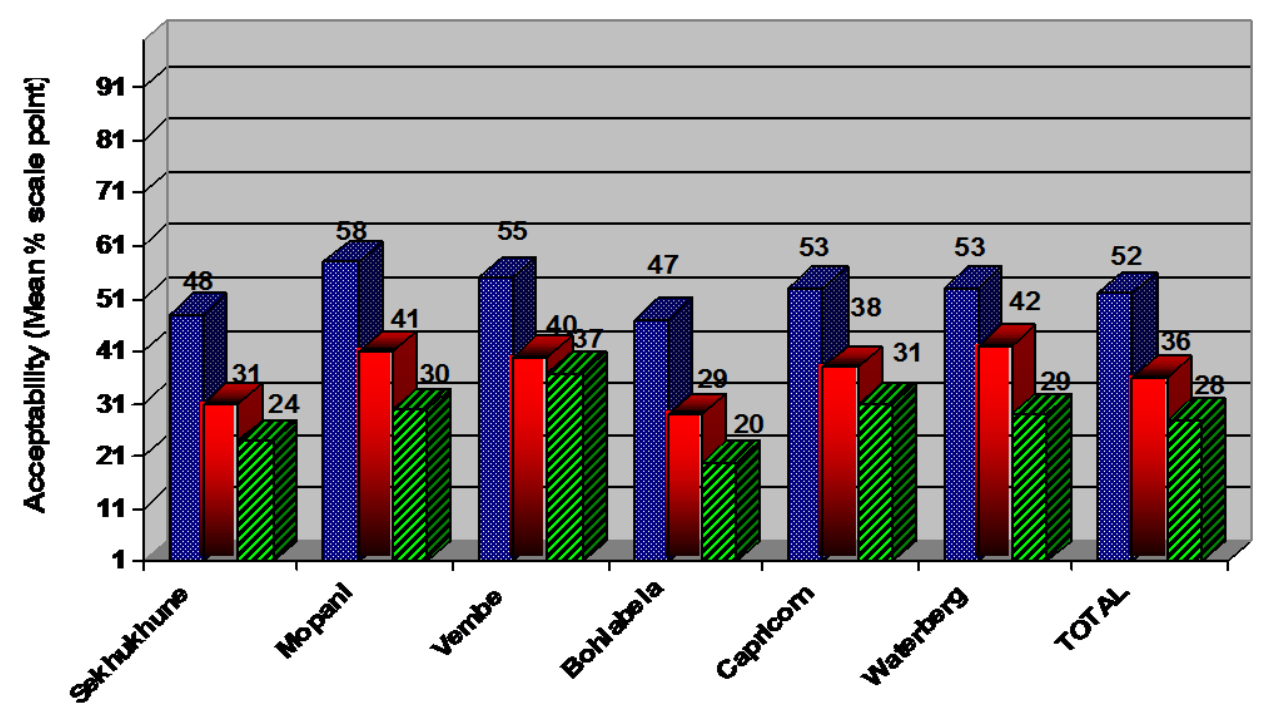

In-sourcing of $\mathrm{m}$ anagem ent/knowledge $\square$ Outs ourcing of personnel $\square$ Outs ourcing of total service

Figure 6: Assessments by respondents in the different provinces of the acceptability of insourcing of management/expertise, outsourcing of personnel and outsourcing of total service, expressed as mean percentage scale points

The general picture of Figure 6 is that there is a very significant difference in the outcome of the three alternatives. The in-sourcing of management or expertise is the most favoured form of all the alternatives tested. This applies without exception to all the districts. The possible reason is the reasoning that this alternative does not threaten the job security of the respondents in the sense that it strengthens the organisation and its potential sustainability. The other two alternatives are not supported. The outsourcing of personnel varies from 29 to 42 mean percentages, while the outsourcing of total services falls below 38 percent in all districts. Both these alternatives have the potential of creating redundancy among respondents. This view is consistent with previous findings which clearly demonstrated the resistance to privatization. 


\section{OUTSOURCING TO BENEFICIARIES}

Farmer Associations in many parts of the world have taken on the responsibility for providing agricultural extension services to their members. The extension services offered by these associations cover a wide range of commodity specific topics. Such countries include Zimbabwe (crocodile producers), Bolivia (Integrated Farmers' Cooperative), India (Operation Food: Dairy), Thailand (Eastern Poultry Raisers Group), Uganda (Vegetable cooperative) and Turkey (Umali, 1996).

A specific form of outsourcing to beneficiaries, implies that the ownership of extension is transferred to the communities or clients, which is often seen as one of the ultimate goals of development (i.e. help towards self-help) but not only as far as individuals are concerned, but within the context of the total community. This alternative can vary from ownership restricted to a section of the total client community or to the total client community (Düvel, 2002:171).

Respondents were asked to indicate their preferences regarding alternative outsourcing beneficiaries such as the local community organization, Local municipality, and District Municipality and district municipality officials. The views are summarized in Figure 7.

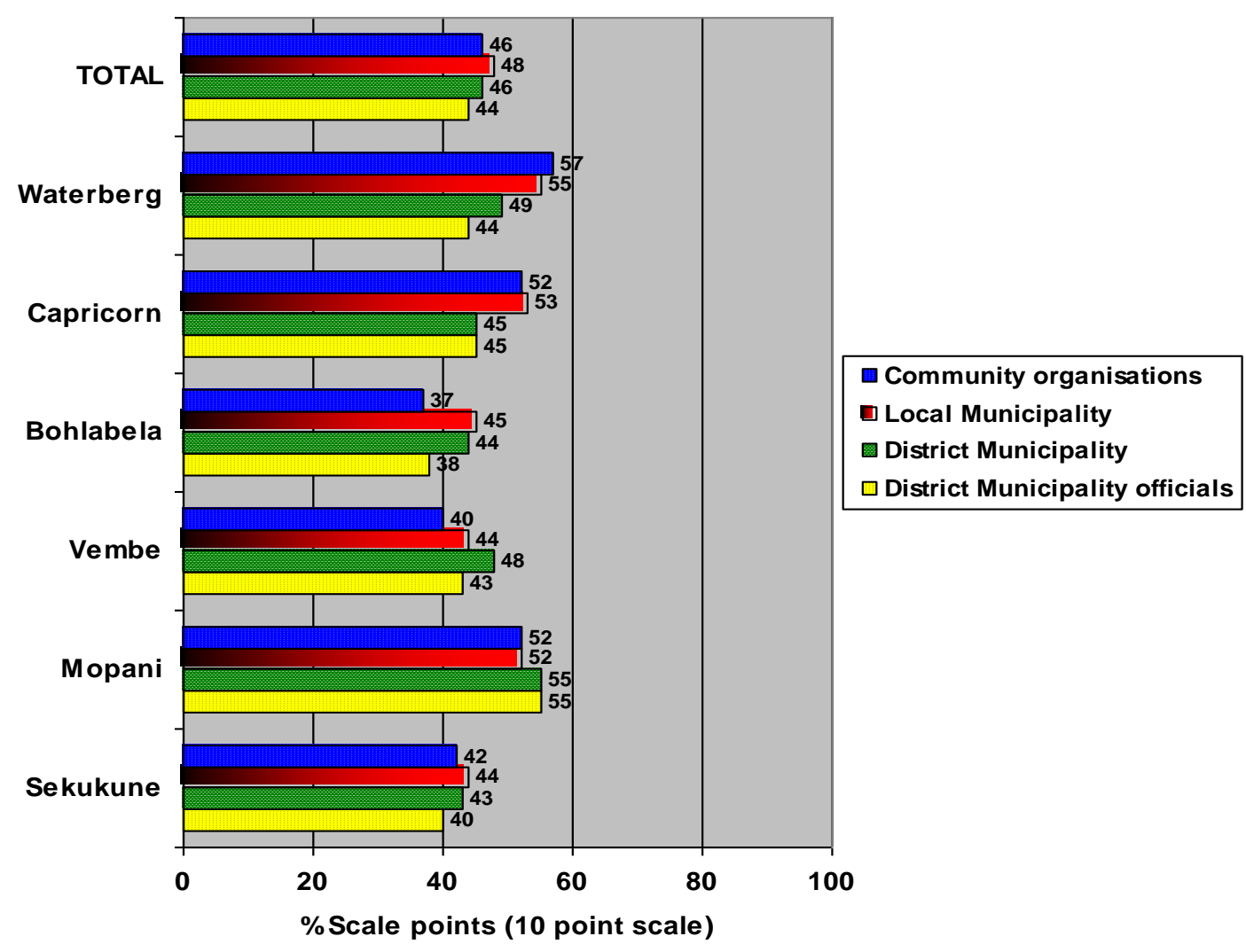

Figure 7: The acceptability of different variations of community owned extension as assessed by respondents in the different Districts of Limpopo Province and expressed as mean percentage scale points 
S. Afr. J. Agric. Ext.,

Zwane

Vol. 44, No. 2, 2016: $71-83$

DOI: http://dx.doi.org/10.17159/2413-3221/2016/v44n2a391

(Copyright)

These findings do not reveal that outsourcing to communities is a popular alternative or a clear preference. This could reflect confusion among the respondents regarding the principles involved, but could also be attributed to a resistance based on a general lack of confidence in communities since the beneficiaries are not believed to be ready to be empowered. The varying choices could therefore be attributed to different judgements of competence of the alternative community structures. The respondents did not support a situation where officials from Local Government would take over the responsibility of extension services.

\section{CONCLUSIONS AND RECOMMENDATIONS}

This section provides conclusions and makes some relevant recommendations. It can be argued that the extension services of different provinces are not as effective as one would like to see them (Düvel, 2002). This is also true in Limpopo, the extension advisors perceived extension services' efficiency to be operating below the international standard, for example when it was assessed against the input /output ratio of R100/ R130 it was found performing below R130 i.e. R89 - R102. Extension advisors showed reluctance to any form of privatization and outsourcing.

Further findings regarding privatisation of extension lead to the following conclusions and recommendations:

The path of privatisation should be treated with care as this was seen from the results of respondents. It can be concluded that the topic of privatization appears to be an emotional issue, and seems to evoke affective responses, probably stemming from feelings of insecurity or fear of ultimately losing employment and the fear and tends to cloud rational deliberations. Respondents disagreed about its relevance and significance even where circumstances would normally justify it, for instance countries that privatized like Malawi cited inefficiency as a reason (Kraft 1997).

Based on the findings it is recommended that:

- Limpopo should not succumb to any pressure and be forced into large-scale privatization of the state extension service. It is argued that based on the results about privatization in developing countries there are no convincing case that has been successful where it has been tried. Extension models that empower communities toward ownership should be encouraged. Currently the partnership model still seems to be the most appropriate and should be purposefully pursued.

- It is further recommended that the Department should investigate other forms of improving efficiency of extension other than privatization route. The reason is that small scale farmers will not afford to pay for the services of extension once it is privatized.

\section{REFERENCES}

BEBBINGTON, A. J. \& SOTOMAYOR, O. 1995. Demand-Led and Poverty-Oriented or just Sub-Contracted and Efficient? Learning from (Semi)-Privatised Technology Transfer Programmes in Chile. ODA project R6056CA. Oxford: FSG.

BEYNON, J. G. \& DUNCAN, A. D. 1996. Financing of Agricultural Research and Extension for Smallholder Farmers in Sub-Saharan Africa: Summary Report and Operational Guidelines, July 1996, ODA project R6056CA. Oxford: FSG. 
Vol. 44, No. 2, 2016: $71-83$

DOI: http://dx.doi.org/10.17159/2413-3221/2016/v44n2a391

BEYNON, J. G. \& MBOGO, H. S. 1996. The Case of Agricultural Research in Kenya, July 1996, ODA project R6056CA. Oxford: FSG.

BEYNON, J. G. \& MUDIMU, G. 1996. The Case of Agricultural Research in Zimbabwe, May 1996, ODA project R6056CA. Oxford: FSG

DÜVEL, G. H. 2002. Towards developing an appropriate extension system for South Africa. National research project. National Department of Agriculture.

EHRET. W. 1997. Reorientation of extension. A Case Study of Participatory Action Research with a Non-Government Organization in Northern Nigeria. (Unpublished Thesis for $\mathrm{PhD}$ ).

FERRIS, S., ROBBINS, P., BEST. R., SEVILLE, D., BUXTON, A., SHRIVER, J., \& WEI, E. 2014. Linking Smallholder Farmers to Markets and the Implications for Extension and Advisory Services MODERNIZATION OF EXTENSION \& ADVISORY SERVICES. Discussion Paper 4. USAID, From the American People.

KIDD, A. LAMMERS, J. FICARELLI, P. \& HOFFMAN, V. 1998. Privatising agricultural extension: Caveat emptor. Department of Agricultural Communication and Extension. University of Hohenheim, Germany.

KRAFT, J. N. 1997. Public and private extension: Who pays and provides. Paper delivered in the Annual Conference: South African Society for Agricultural Extension, Aventura, Warmbad.

OZOR, N, GARFORTH, J. C. \& MUDUKWE. C. M. 2011. Farmers willingness to pay for agricultural Extension Service from Nigeria .J. Int.Dev. available: http://dx.doi.org/10.1002/jid.

RIVERA, M. W, \& CARY, J. W. 1997. Privatising agricultural extension. Gradual "Privatisation" In: (Ed) Swanson, B. E., Bentz, R. P. and Sofranko, A. J. Improving Agricultural extension. A reference manual. Food and Agriculture Organization of the United Nations. Rome.

RIVERA, M. W. \& ALEX, G. 2004. Privatisation Extension Systems. Case studies of International Incentives. Discussion Paper 9. World Bank Publications, Washington DC.

SARAVANIAN, R. 1999. A study on privatization of agricultural Extension Services. MSc Thesis, Department of Agricultural Extension. University of Agricultural Sciences (UAS), GKVK, Bangalore, India.

STLLWEL, T. \& BOTHA, A. C. 1997. Report on an investigation of National Agricultural Extension System of South Africa on privatization (Unpublished).

TACKEN, W. 1996. The Dutch extension service. The change from a publicly funded Extension Service to a privatised, client - oriented organization. In: Extension workshop. Alternative Mechanisms for Funding and delivering Extension, SA2, The World Bank. Washington, D.C.

UDDIN, M. E. Q., GAO, Q. \& MAMUN-UR-RASHID, M. D. 2014. Farmers Willingness to Pay for Agricultural Extension Services in Bangladesh: Cases of Selected Villages in two Agro-ecologicalzones. Journal of Agricultural Education and Extension 1-81. I first. Available online on: http://dx.doi.org/1080/1389224x.2014.971826 Accessed on the $07 / 10 / 2016$

UMALI, D. L. 1996. New approaches to an old problem: The public and private sector in extension. In: Extension workshop. Alternative Mechanisms for Funding and delivering Extension, SA2, The World Bank. Washington, D.C.

VENKATA, K. 2000. Privatization of agricultural Extension System in India presented at National Seminar on private extension. July 28-29, Manage Hyderabad (AP), India. 